\title{
Speech Disguise (Bird Talk) and its Role in Phonological Analyses
}

\author{
Hasmik Hovhannisyan \\ Yerevan State University
}

I n this article I present an Armenian-based speech disguise which, I assume, provides sound evidence for the internal hierarchical structure of Armenian syllables, certain relations between the subsyllabic constituents in the process of syllabification, as well as prosodic/metrical structure of the language.

However consistently some theorists (Ohala \& Kawasaki-Fukumori 1997:343-365; Steriade 1997, 1999:205-242) try to underestimate or even deny the significance of the syllable in phonological analyses; Armenian syllabification facts strongly support the syllable-based analyses. Moreover, the facts discussed in this article pretend to add more evidence to the relevance of the syllable-based phonological and psycholinguistic approaches. Syllables play an important role in phonological awareness, speech processing and reading (Ferrand, Segui \& Humphreys 1997:458-470).

Language games and speech disguises (also known as ludlings, from the Latin ludus - game and lingua - language) are not created independently, in a vacuum. They employ rules and principles mostly characteristic of a source language. Thus, creating various alternations and linguistic contexts that simply cannot or do not normally occur in a language, "they often reveal crucial information about the structure of a language or a language in general" (Walter 2002:178). These particular alternations and theoretical accounts for why they take the forms that they do and how the phonological units are treated in those systems, tell the theorists much about the nonlinear representations, metrical structures, prosodic operations, etc. of the base language. Bagemihl claims that ludlings are an integral part of human linguistic capacity and as such constitute an integral part of linguistic theory (Bagemihl 1995:711).

The speech disguise to be analysed further in this article is especially interesting in a sense that it is not spoken by some particular social or age group. The age of the speakers of this ludling ranges from schoolchildren to elderly people (mostly illiterate). The speech disguise named "Bird Talk" constitutes an important part of the oral culture of this rural community (therefore, manipulation of spelling in their communication should probably be excluded). Bird Talk is based on the normal speech of Armenian; it involves systematic alternation to it consisting of infixation. There are no explicit instructions or "rules" about how to speak this language (note the age and different levels of education of the "learners"). The ludling is acquired simply by being exposed to it and later on involved in communication.

Bird Talk, like the English Ubby Dubby or Ibenglibish, employs an iterative infixation mechanism (Yu 2008). Affix /og/ is inserted between the onset and rime (or rhyme). This particular insertion site may be explained by the fact that manipulations that respect the unity of onsets and rimes are more easily learned than those that do not (Treiman 1983:49-74, 1986:471-496). The stress is on syllable following the insertion site. Thus, -əg- is inserted before every nucleus yielding (C) əgV syllables. Those, in turn, are parsed as (C) ə.gV', e.g. 
(1)

$\begin{array}{ll}\text { Source word } & \text { Ludling word } \\ \text { mori (raspberry) } & \text { mə.go-rə.gi } \\ \text { aman (summer) } & \text { ə.ga-mə.gaR }\end{array}$

The stress in assigned to the second (final) syllable. As the analysis shows this ludling imposes strict prosodic condition on the output forms. Examples above display a systematic rhythmic alternation of unstressed and stressed syllables. - əg- is inserted into each syllable so as to form a iamb (metrical structure characteristic of non-ludling Armenian):

(2)

$\begin{array}{lll}\text { Source word } & \text { Ludling word } & \text { Iambic foot } \\ \text { hajr 'father' } & \text { hə.gajr } & \left(.^{*}\right) \\ \text { jeram 'flock' } & \text { jə.ge.rə.gam } & \left(.^{*}\right)\left(.^{*}\right) \\ \text { abavni 'pigeon' } & \text { ə.ga.bə.gav.nə.gi } & \left(. .^{*}\right)\left(.^{*}\right)\left(*^{*}\right)\end{array}$

It should be noted that in bisyllabic feet the rimes of the source words occur in a foothead position. This, I assume, is not accidental. Rimes in Armenian constitute mostly the bigger part of syllables as compared to non-branching onsets (cf. C.VC or C.VCC). Hence, rimes may convey more information about the source word and thus serve as perceptual support for the 'speakers'. Being in a strong position, i.e. in the foot head, makes the source syllable maximally stand out via stress (Harris 2000: 3): (3)

\begin{tabular}{|c|c|}
\hline $\begin{array}{l}\text { Source word } \\
\text { hart"s.nél 'ask' } \\
\text { ajr.vátsk 'burn' } \\
\text { hajt's.vór 'applicant' } \\
\text { sand.bák 'scale' }\end{array}$ & 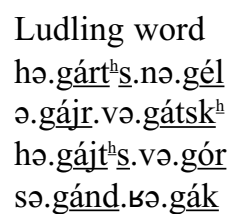 \\
\hline
\end{tabular}

The rhythmic alternations of the "disguised" words, i.e. the output representations, are controlled by the constraints on the well-formedness of feet in the language. In general, the left edge of each source syllable must correspond to the left edge of a foot in the output form. As the speech disguise in question demands that the disguised words be parsed into bisyllabic strings of iambs, syllabic foot binarity is satisfied through affixing a monosyllable, e.g. sur 'sabre' $\rightarrow$ sə.gúr, katú 'cat' kə.gá.tə.gú, jesanák-'weather' $\rightarrow$ jə.gé.bə.gá.nə.gák, where the schwa of the affix /əg/ and the vowel of the source syllable rime secure the requirements of bisyllabic feet:

(4)

\begin{tabular}{|c|c|c|c|}
\hline $\begin{array}{l}\text { Source word } \\
\text { súr 'sabre' }\end{array}$ & $\begin{array}{l}\text { Ludling word } \\
\text { sə.gúr }\end{array}$ & $\begin{array}{l}\text { Source syllable(s) } \\
\sigma \\
\mid \\
\mathrm{N} \\
\mid \\
\text { sur }\end{array}$ & 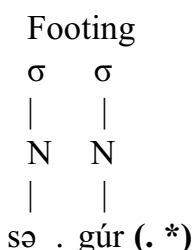 \\
\hline
\end{tabular}


katú 'cat'

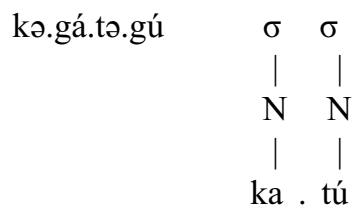

$\begin{array}{cccc}\sigma & \sigma & \sigma & \sigma \\ \mid & \mid & \mid & \mid \\ \mathrm{N} & \mathrm{N} & \mathrm{N} & \mathrm{N} \\ \mid & \mid & \mid & \mid \\ \text { kə. gá. tə. gú }\left(.^{*}\right)(. *)\end{array}$

This far the affixation strategy may look quite straightforward and simple. There are, however a couple of points worth discussing:

i. How are the disparities between the underlying and surface forms translated into the Bird Talk?

ii. Are all the phonotactic constraints of source language treated similarly in the speech disguise?

So far, the examples (in (1), (2), (3)) had CV(C) or CVC(C) syllable structure. Let us now consider an underlying $\mathrm{CCV}(\mathrm{C})$, and sibilant + stop (ST) VC forms: $\mathrm{CCV}(\mathrm{C})$, as discussed earlier in this paper, will be parsed as (a) C.CVC and (b) STVC will take a form of S.T.VC (according to the Minimum Allowable Onset Principle (MAOP):

(5)

\begin{tabular}{|c|c|c|c|c|}
\hline Source word & $\begin{array}{l}\text { Syllable } \\
\text { parse }\end{array}$ & Epenthesis & Ludling word & Gloss \\
\hline a. $C C V C$ & C.CVC & Co.CVC & Co.go.Co.gVC & \\
\hline$/ \mathrm{k}^{\mathrm{h}} \mathrm{sak} /$ & $/ \mathrm{k}^{\mathrm{h}} \cdot \mathrm{sak} /$ & {$\left[\mathbf{k}^{\mathrm{h}} \partial . \mathbf{s a k}\right]$} & $k^{\mathrm{h}}$ ə.gə.sə.gak & 'purse' \\
\hline$/$ slak $^{\mathrm{h}} /$ & /s.lak ${ }^{\mathrm{h}} /$ & [sə.lak $\left.\mathbf{k}^{\mathrm{h}}\right]$ & sə.gə.lə.gak ${ }^{\mathrm{h}}$ & 'arrow' \\
\hline /vtak/ & /v.tak/ & [və.tak] & və.gə.tə.gak & 'stream' \\
\hline /Jnorh/ & / .norh/ & [〕ə.nor] & ๑ə.gə.nə.gor & 'grace' \\
\hline b. STVC & STVC & oS.TVC & o.gวS.To.gVC & \\
\hline /skizb/ & /s.kizb/ & [əs.kizb] & ə.gəs.kə.gizb & 'beginning' \\
\hline /zguj]// & /z.gujf/ & [əz.guj]] & ə.gəz.gə.guj & 'careful' \\
\hline$/$ ppar/ & $/ \int \cdot \operatorname{par} /$ & [ə].par] & ว.gəf.pə.gar & 'makeup' \\
\hline /spitak/ & /s.pi.tak/ & [os.pi.tak] & ə.gəs.pə.gi.tə.ga & 'white' \\
\hline
\end{tabular}

The speakers of Bird Talk, as I assume, use surface representations as input. One good reason for them to do so may be the fact that the underlying forms of source language surface having already undergone the necessary phonotactic changes to satisfy the Universal and language-specific well-formedness conditions.

Manipulating ready-made well-formed syllables of the source language is more reasonable and easier than to undergo several stages from the underlying representations to ludling forms. Thus, starting with the underlying form of e.g. /k.rak/ would require a speaker to insert -əg- in it which would take the form kə.g.rák. Here, apparently the second syllable of kə.g violates foot binarity. The next step for a speaker would be to think of augmentation strategy, that is - to fill the empty nucleus position of kə.g ${ }^{\prime}$. .rə.gák which is also a potential stress-bearing nucleus position.

Thus, kə.g $\square^{\prime}$ is an ill-formed ludling syllable with respect to two factors: (i) the g $\square^{\prime}$ syllable misses the obligatory nucleus constituent;

(ii) kə.g $\square^{\prime}$ violates the foot binarity: 
(6)

\begin{tabular}{|c|c|}
\hline (i) $* \sigma$ & (ii) $* \sigma \sigma$ \\
\hline 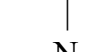 & $\mid$ \\
\hline IV & iv \\
\hline $\mathrm{g} \square^{\prime}$ & \\
\hline
\end{tabular}

Another problem for a speaker to deal with this source syllable is to think of how to fill the nuclear position: the augmentation of the nucleus can be achieved either by copying the nucleus vowel of the affix (schwa in this case) or by inserting some form of default vowel segment:

(7)

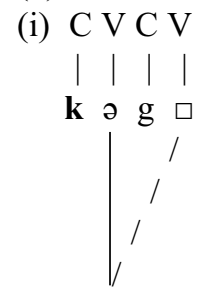

(ii) $\mathbf{k}$ ə $\mathrm{g} \square$<smiles>C1=CCCCC1</smiles>

C V C V(default)

To avoid all these stages, a Bird Talk speaker simply takes the surface form of a source syllable and makes the necessary extensions. The surface epenthetic schwa does a great deal of work here: all nuclei surface filled:

(8)

$\begin{array}{lcll}\text { Underlying form } & \begin{array}{c}\text { Epenthesis } \\ \text { (Surface form) }\end{array} & \text { Ludling form } & \text { Gloss } \\ \text { /k.rak/ } & {[\mathrm{kə} . \mathrm{rak}]} & \text { kə.gə.rə.gak } & \text { 'fire' } \\ \text { /s.xal/ } & \text { [sə.xal] } & \text { sə.gə.xə.gal } & \text { 'mistake' }\end{array}$

$\operatorname{STV}(C)$ forms are manipulated the same way as the $\operatorname{CCV}(\mathrm{C})$ forms, that is - the disguised forms deal with the surface representations only; eg.: /skahak/'cup' $\rightarrow$

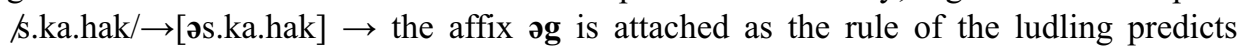
ə.gə’s.kə.gá.hə.gák.

The speakers of Bird Talk are incredibly good at dealing with initial coda sibilants. This is also obvious in their connected speech: (9)
Underlying source a./du mi sks-ir/
b./ed mard-n spa tfe/ sentence
Surface syllabification [du.mis.kə.sir] [ed.mard.nəs pa.tfe]

Bird Talk translation də.gú.mə.gís.kə.gə’.sə.gír ə.géd.mə.gárd.nə.gə’s.pə.gá.t ə.gé

Gloss 'You do not start' 'That man is not an officer' 
Besides, it is the oral speech that is being manipulated which in turn is identified with surface forms, in other words, the ludling manipulates the phonetic forms of the words. Hence, underlying silent or/and geminate segments are ignored, e.g.

Underlying form

$$
\begin{aligned}
& \text { Phonetic form Ludling form Gloss } \\
& \text { [a].xa.rik] ə.gaf.xə.ga.rə.gik 'secular' } \\
& \text { /tfa.na.par.hord/ [tfa.na.pa.rord] t t J.ga.nə.ga.pə.ga.rə.gord 'traveller' } \\
& \text { [u.ва.ki] ə.gu.ьə.ga.kə.gi 'simply' } \\
& \text { /tarrakan/ [ta.ra.kan] tə.ga.ro.ga.kə.gan 'elementary' }
\end{aligned}
$$$$
\text { /uвьаki/ }
$$

The next point to be discussed is whether all the phonotactic constraints of the Armenian source language are treated similarly in the Bird Talk.

As a matter of fact, Bird Talk employs well-formed source language syllables, inserting a $\mathrm{VC}($ əg) affix into licit $(\mathrm{C})(\mathrm{C}) \mathrm{V}(\mathrm{C})(\mathrm{C})$ syllables which in turn yield absolutely legal CV.CV $(\mathrm{C})(\mathrm{C})$ or V.CV $(\mathrm{C})(\mathrm{C})$ sequences:

$\begin{array}{lllll}\text { Syllable type } & \text { Source word } & \text { Affix /əg/ } & \text { Bird talk word } & \text { Gloss } \\ \text { CV } & \text { bu } & \text { bə.gu } & \text { bə.gú } & \text { 'owl' } \\ \text { VC } & \text { i3 } & \text { ə.gi3 } & \text { ə.gí3 } & \text { 'viper' } \\ \text { C.CV } & \text { kə.tsu } & \text { kə.gə.tsə.gu } & \text { kə.gə'.tsə.gú } & \text { 'hot' } \\ \text { VCC } & \text { ajt } & \text { ə.gajt } & \text { ə.gájt } & \text { 'cheek' } \\ \text { CVC } & \text { sar } & \text { sə.gar } & \text { sə.gár } & \text { 'mountain' } \\ \text { C.CVC } & \text { xə.rat } & \text { xə.gə.rə.gat } & \text { xə.gə'.rə.gát } & \text { 'advice' } \\ \text { CVCC } & \text { mirk } & \text { mə.girk } & \text { mə.gírk } & \text { 'fruit' } \\ \text { C.CVCC } & \text { bə.rindz } & \text { bə.gə.rə.gindz } & \text { bə.gə'.rə.gíndz } & \text { 'rice' }\end{array}$

A similar treatment does not hold, though, for source syllables containing initial consonant clusters with a glide segment in them, like kjank $^{h}$ (life), bjur (many), njut (mate-

\begin{tabular}{|c|c|}
\hline$* \sigma \quad \sigma$ & $\sigma \quad \sigma$ \\
\hline$\wedge \wedge$ & $\wedge \wedge$ \\
\hline $\mathrm{ONONO}$ & $\mathrm{ONON}$ \\
\hline$\wedge|| l \mid$ & $1|1|$ \\
\hline
\end{tabular}
rial), gjив (village), skjuR (squirrel), djurin (easy), etc. While Cj clusters in Armenian do not violate Minimum Allowable Onset Principle (MAOP):

(12)

djurin 'easy'

Bird Talk does not tolerate even a palatalised onset consonant. (Note that it does not treat final CC clusters any differently from the source syllables). Leaving the rime constituents intact, the rules of Bird Talk first split the $\mathrm{Cj}$ cluster (Idsardi 2005) then the epenthesis strategy of the source language is adopted and exploited on a form which the ludling treats as an initial C.C cluster (C.j). It surfaces epenthesised - Cə.C (sə.jun 
“colomn” by analogy with, e.g. srah-sə.rah "hall". This very CəCVC form serves as input for ludling word formation:

(13)

$\begin{array}{lllll}\text { Source word } & \text { Ludling parse } & \text { Epenthesis } & \text { Ludling word } & \text { Gloss } \\ \text { CjVC(C) } & \text { C.jVC(C) } & \text { Cə.jVC(C) } & \text { Cə.gə.jə.gVC(C) } & \\ \text { hjur } & \text { h.jur } & \text { hə.jur } & \text { hə.gə.jə.gur } & \text { 'guest' } \\ \text { dzjun } & \text { dz.jun } & \text { dzə.jun } & \text { dzə.gə.jə.gun } & \text { 'snow' } \\ \text { kjank }^{\text {h }} & \text { k.jank } & \text { kə.jank } & \text { kə.gə.jə.gank } & \text { 'life' }\end{array}$

Syllables with SCj clusters are converted into Bird Talk in following steps:

1. $\mathrm{S}$ is assigned to a coda ə.gəS,

2. The legal source onset $\mathrm{Cj}$ is split into two 'syllables' C.CVC $=\mathrm{C} . \mathrm{jVC}$,

3. The onset and infix segments are mapped onto a well-formed bisyllabic foot,

4. The rightmost rime is treated as usually.

Let us see how this procedure works on actual examples:

Source word

1. Assign initial $\mathbf{S}$ to coda

2. Split the $\mathbf{C} \mathbf{j}$ cluster

3. Form a bisyllabic foot

4. Treat the remaining syllables

Ludling word

skjuR 'squirrel'
əs.kjuR
əs.k(ə).juR
ə.gəs. kə.g(ə)
jə.guR
ə.gəs. kə.gə.jə.guR

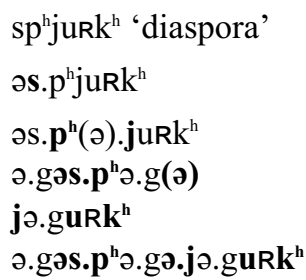

Crucially, as it appears, the reason for fracturing the legal onset segments is not phonologically conditioned. To a question why the $\mathbf{C} \mathbf{j}$ onset is disfavoured as a solution in the game, one of the ludling "speakers" explained that the fracturing the beginning of the source $\mathrm{CC}$ words makes the ludling word more difficult to decode. This claim by a naive speaker (i.e., someone without linguistic training) is compatible with the hypothesis that in speech perception syllable onsets "provide privileged entry or reference points for segmentation and lexical access" (Content et al 2001:197). Hence the aims of a speech disguise to conceal a conversation from outsiders. The speakers split the initial consonant segments - even those permitted in non-ludling Armenian - to make the process of lexical access as complicated as possible. The present results provide further evidence for the view that syllables in Armenian have a hierarchical structure.

The examination of the rules of the speech disguise, in general, testify to the fact that even illiterate people may have an incredible command over the language they speak, manipulate syllables and employ syllabification strategies as well as acquire a speech disguise without even consciously knowing the "rules" (Denham 2005).

The analysis of the Bird Talk - an Armenian speech disguise - turns out to be quite an interesting and specific way to learn about the native Armenian speakers' intuitions about their language structure (syllables, syllable-internal hierarchical relations, metrical properties), and which is even more interesting to find out about the native speakers' unconscious awareness of perceptual processes and manipulating them. 
The very fact of inventing and passing on ludlings in oral cultures is enough to suppose that both universal and language-specific rules and principles have control over the forms the ludling takes. The metrical spell-out of this particular ludling quite obviously contains the foot structure and the stress of the Armenian word.

\section{References:}

1. Bagemihl, B. (1995) Language Games and Related Areas. // Handbook of Phonological Theory. / Ed. by J.A. Goldsmith. UK: Blackwell Publishers.

2. Content, A.; Kearns, R.K. \& Frauenfelder, U.H. (2001) Boundaries versus Onsets in Syllabic Segmentation. // Journal of Memory and Language 45. Amsterdam.

3. Denham, K. (2005) Ludlings Teach Language Diversity and Change: From Pig Latin to Ubby Dubby. Pittsburgh, Pennsylvania: Western Washington University NCTE.

4. Ferrand, L.; Segui, J. \& Humphreys, G.W. (1997) The Syllable's Role in Word Naming. // Memory \& Cognition, 25.

5. Harris, J. (2000) The Foot as a Segmental Domain. // Phonology Meeting; Workshop: Segmental Markedness and Syllabic position. Manchester $<$ http://www.englang.ed.ac.uk/mfm/harris.pdf $>$

6. Idsardi, W. \& Raimy, E. (2005) Remarks on Language Play. Ms.: University of Maryland and Swarthmore College.

7. Ohala, J.J. \& Kawasaki-Fukumori H. (1997) Alternatives to the Sonority Hierarchy for Explaining the Shape of Morphemes. // Language and its Ecology: Essays in memory of Einar Haugen. / Ed. by S. Eliasson \& E.H. Jahr. Berlin: Mouton de Gruyter.

8. Steriade, D. (1997) Phonetics in Phonology: The Case of Laryngeal Neutralization. Ms.: University of California.

9. Steriade, D. (1999) Proceedings of the 1998 Linguistics and Phonetics Conference. / Ed. by O. Fujimura B. Joseph and B. Palek. Prague: The Karolinum Press.

10. Treiman, R. (1983) The Structure of Spoken Syllables: Evidence from Novel Word Games. // Cognition, 15.

11. Treiman, R. (1986) The Division between Onsets and Rimes in English Syllables.// Journal of Memory and Language, 25.

12. Walter, M.A. (2002) Kalaam, Kalaarbaam: An Arabic Speech Disguise in Hadramaut. // Texas Linguistic Forum 45. Proceedings of the Tenth Annual Symposium about Language and Society, April 12-14. Austin.

13. Yu, A.C.L. (2008) On Iterative Infixation. // Proceedings of the 26th West Coast Conference on Formal Linguistics. / Ed. by Charles B. Chang and Hannah J.Haynie. Somerville, MA: Cascadilla Proceedings. 


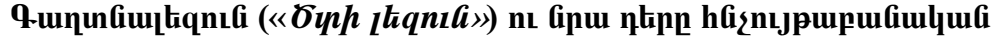 lkpцnıdnıpjuif uitis}

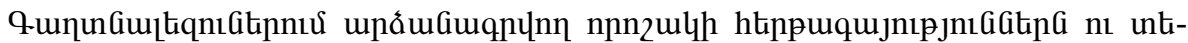

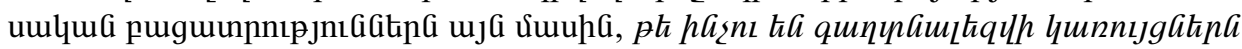

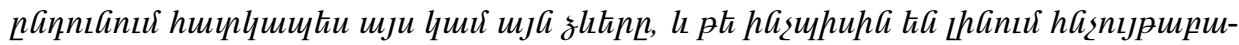

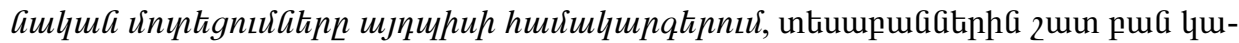

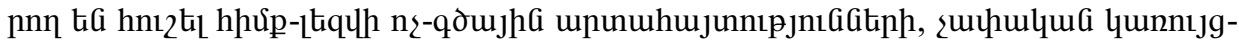

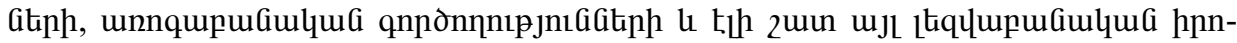

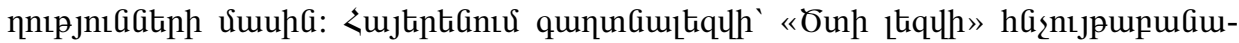

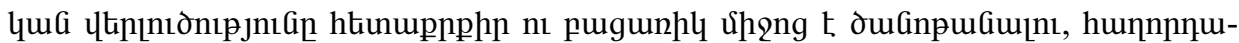

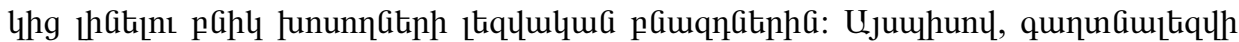

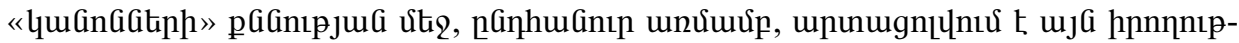

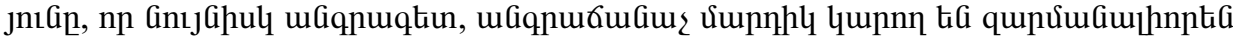

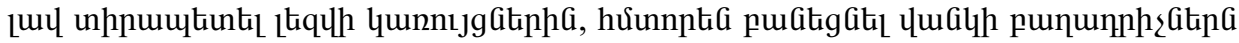

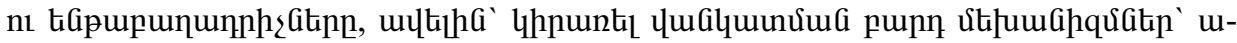

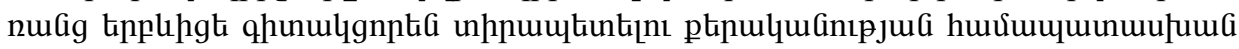
quangitinha: 